\title{
An evaluation of marketing strategies undertaken by Coca Cola Company as a multinational corporation in Nigeria
}

\author{
${ }^{1}$ Danjuma Naisla Hassan, ${ }^{2}$ Audu Anyesha Amos ${ }^{3}$ Omaku Angulu Abubakar \\ ${ }^{I}$ Department of General Studies, Nasarawa state polytechnic lafia. Nasarawa state of Nigeria. \\ ${ }^{2}$ Department of Social sciences (business management unit) school of basic and remedial studies, \\ Nasarawa state polytechnic lafia. Nasarawa state of Nigeria. \\ ${ }^{3}$ Department of Pre-ND, Nasarawa state polytechnic lafia. Nasarawa state of Nigeria.
}

\begin{abstract}
This research tend to evaluate the marketing strategies make use of by Coca Cola Company in Overseas market particularly Nigeria. The four (4) basic marketing strategies which are commonly called the $4 p s$ which denote price, product, promotion and place are exceedingly used by Coca Cola Company in Nigeria. Coca Cola Company strategy of sales was price penetration where low price are charged and the company attends large market as possible. Unlike price skimming where higher price are charged. Product strategy was strongly applied such as the modification of its product as well as after sales services which all help to facilitate the marketing of the product. Promotion strategy which includes the sales promotion, technological change and advertisement were all used by coca cola Company in the marketing of its product in Nigeria. Finally place strategy which involve selection of distribution channels, transport arrangement etc which are very essential to the corporation was used. For example coca cola Company have twelve (12) factory plants, sixty (60) depots and over four hundred thousand $(400,000)$ dealers or retailers of coca cola product in Nigeria.
\end{abstract}

Key words: Enterprises, firms, marketing, international, coca cola Company, strategies.

\section{Introduction}

Coca-cola Company is one of the fastest growing multinational enterprises in Nigeria. History has shown that the coca-cola company has touched so many lives since World War II Retroplanet(2008). However, to examine the ways in which the coca-cola company has used marketing strategies to grow in the overseas markets, more especially Nigeria, and to also evaluate the strategic responses it has made or might make when entering overseas markets, it is imperative to know briefly the history of the coca-cola company.

\section{A Brief History Of Coca-Cola Company}

The history of Coca-Cola Company as portrayed by Retroplanet (2008) that, it was first invented by John Stith Pemberton in 1886 as a drink meant to impart good health and stamina. Pemberton was a pharmacist from Columbus, Georgia who originally made a Coca wine called Pemberton's French wine coca in 1885. When prohibition laws were passed within his country, Pemberton position out to make a new non-alcoholic drink. What he creates was pleasant tasting syrup that could be mixed with carbonated water and served at the soda fountain as a refreshing drink. He first sold this drink for five [5] cents a glass at his establishment Jacob's pharmacist in Atlanta, Georgia. The average sales for the first eight months average nine glasses a day. Another Atlanta pharmacist and businessman, Asa Griggs Candler brought into Pemberton Company, and in the following year, pemberton sold Candler his remaining interest in the company.

Asa Candler purchase exclusive rights to the coca-cola formula in 1891 and by the subsequent year had increased sales ten times over. Sales were going so well that Candler sold his pharmaceutical business and committed himself fully to the success of coca-cola. His brother, John and pemberton former partner frank Robinson joined Candler and together they formed the coca-cola company.

The trade mark "coca-cola" was registered in the US patent office on January 31, 1893.Candler constantly grow the business with persuasive advertising and distributing thousands of free drinks coupons. In 1894 the popular drink was sold in bottles for the first time. Beginning in 1899, independent bottling companies were licensed to bottle the drink, a practice that is still in use today by US soft drink industry.

In 1920 to 1926 Robert woodruff was president and established the foreign department, which in 1930 became a subsidiary of coca-cola known as the coca-cola export corporation. Woodruff was dogged to expand of the coca-cola company internationally. Plants had already been built in France, Cuba, Panama, Canada, Puerto Rico, the Philippines and Guam.

Woodruff brings out the world-shattering new 6 bottles cartons that made it easier to take bottles of coca-cola home. In 1928, sales of coca cola in bottles go beyond sales at the soda origin for the first time. In 1929 metal top opening coolers were created to dispense bottles of ice-cold coca cola in stores and filling stations. 
Mechanical soda dispensers made their entrance in 1933 at the Chicago world's fair when coca cola introduced the dole master dispenser. This was the first soda dispenser that was able to mix the carbonated water and soda syrup together automatically which was then dispensed merely with a pull of the handle.

When the world war II broke out Robert woodruff was quoted as saying that he wanted to "see that every man in uniform get a bottle of coca cola for 5 cents. Wherever he is and whatever it cost the company". During the war, 64 bottling plants were constructed as closed as was possible near areas of combat in North Africa, the pacific and Europe. Military personnel consumed more than 5 billion bottles of coca cola during World War II.

The coca cola company introduced diet coke in 1982. This was the first extension of the coca cola and coke trademark. In two years time, diet coke was the top selling diet soft drink in the world.

In 1985 the formula for coca cola was transformed and the coca cola company free a new coke. There was such a negative reaction to this change that the old formula was re-released within 8 months with the name coca cola classic. On July 12, 1985, the new coke was the first soft drink to be consumed in space, having been place in specially designed cans just for the trip on the space competitor. These containers were called the "coca cola space can".

Diet coke became the first diet soft drink consumed in space aboard the space transport discovery in February 1995.this trip marked the first time soda fountain equipment was used in space.

Today coca cola produces nearly 450 brands in more than 200 countries and rates as one of the most acknowledgeable brand in the world.

\section{Concepts Of International Marketing And Strategies}

International Marketing - this is the activities of a firm or business organisation in making one or more marketing mix decisions across national boundaries Doole and Lowe (2004). That is a situation which involves a firm establishing manufacturing facilities overseas and coordinating marketing strategies across the globe. In international marketing, the world is seen as a market segmented by socio-cultural, legal, economic, political and technological grouping which constitute international marketing environment. For the firm to be successful in his international marketing decision, the above factors must be strictly followed. For example socio- cultural factor includes language, religion and materials culture affect consumers' perception and patterns of buying behaviour. The legal factor also involves the law of the host country in which the firm operate under; this therefore determined the level of the firm operation etc. According to Evans and Berman (1990) in Idio (2010 $=\mathrm{P} 156$ ) state that marketing is the anticipation, stimulation, regulation, facilitation and satisfaction of consumers and public's demand for product, services, organisation, people, place and idea through the exchange process. Therefore in marketing, firm would always consider the future of the economy, demonstrate benefit of their product, product must always be available, have a good and easy service to the consumer and satisfy consumer expectation.

Strategies - according to Johnson etal (2009:219) define strategy as the path and scope of an establishment over the long-term which achieves benefit for the organisation through its composition of resource within a demanding environment, to meet the needs of markets and to accomplish stakeholders' hope. It is about where is the business trying to get to in the long run, which market should a business compete in and what kind of activities are involved in such market? How can the business perform better than the competition in those markets? What resources are required in order to be able to compete? What external environmental factors affect the business ability to compete and what are the values and expectations of those who have power in and around the business. All these are what strategy tends to achieve.

\section{Theoretical Framework Of Business Or Marketing Strategies}

There are many theories of business strategies being forwarded by different academic writers. Amongst these theories includes:

Kenneth Andrew SWOT and PESTLE analysis = this theory was based on the premise that the final strategy adopted by a company should achieve a "fit" between her internal power (strength and weaknesses) and the external situation (opportunity and threat). This is commonly known as SWOT analysis.

The external situation highlighted the general environmental influence that firm must cope with .e.g. political, economic, social, technological, legal and ecological factor (PESTLE)

The internal situation identify those things the organisation does specifically well (strength) and those that limit her ability to fulfil her purpose (weaknesses).e.g. marketing, organisation, personnel and financial features. Wall, et'al (2010:P240) 
Porter's five forces analysis.= Michael porters identified five forces that determined the state of competition in a market. He added that these forces also influence the profitability of firms already in the industry. The five forces analyses was identify as

Threat of potential entrants- the threat to industry here depends on the barriers that survive in the market on the likely reaction of active competitors to the entrant. Porter recognized six sources of barriers to entry. Namely, economies of scale, differentiation of product, capital requirement of entry, cost advantages, access to distribution channels and legislative intervention.

Threat of substitute products-this can bring change to the competitive environment where the firm operate. A recent product may make the existing one worthless. The fear of individual firm is how the substitute would affect his activities. The firm can only be at the safer side by remaining at a low cost point in the industry.

Bargaining power of the suppliers- supplier can crush industry profit through raising prices or lessen quality of products. Porter states that a supplier is powerful if only a small number of them exist in a particular market, if there is no substitute product available, if the industry is not an important customer of the supplier or the supplier product is an important input to the buyer's business.

Bargaining power of the buyer- in reality, the greater the bargaining powers of the buyer, the better the buyer talent to demoralize industry benefits. Porter identify a number of factors of bargaining power to includes, the concentration and size of the buyer in cost terms, the cost of switching stuck between supplier and the extent of standardization of products. Buyer should be treated as rival but should have pleasant rapport foundation on performance and uprightness.

Rivalry among existing firms- the degree of rivalry can determine the competitive environment within which the firm operate. Porter refers to the strategy use by the firm to get reimbursement over their competitors as "jockeying for position". This usually takes the shapes of guidelines towards pricing, promotion, product innovation and service level. Porter further states that tactic formulation necessitate that the above forces be examine very well to victoriously position the company for defence against competitive forces, control the balance of forces through strategic move and anticipate changes in factors underlying the forces and react to them.

\section{MARKETING STRATEGIES OF MULTINATIONAL ENTREPRISES (COCA COLA COMPANY IN OVERSEAS)}

The guiding principle of any business organisation is to maximize profit and any other reason is added. Therefore for any business to be carried out the firm would undergo a strong business research to know the strategies he will employed in order to run a successful business in a given society. Once a survey has been conducted, the firm or organisation would develop a marketing strategy to guide her on marketing activities. However, there are marketing strategies adopted by firms which are classified under the concepts of marketing segmentation and marketing mix. These concepts are further explained by Wall, et'al $(2010=\mathrm{P} 239)$ as follows:

Marketing segmentation - strong choice has to be made as to which market segment to target. Market segment is a group of valuable consumers who posses unique characteristics in common. For example found within certain income range, age rang, or occupational profile. Quite a number of these segments have been identified as more likely to patronize that product than others. Having identified the segment, the organisation would take decision whether to implement one segment or all the segments. Once the decision on which segment to use is taking, the firm can go ahead and make production positioning to the segmented areas.

Segmentation contributed to "niche" or specialist market. That is, people who are more affluent or are highly place in the society demanding product that are of high quality and attract higher prices. Niche market supported the growth of small firm. This is true because large firm has found many of these segments too small to service with the expectation of high benefits.

Marketing mix - according to Bennett $(1998=\mathrm{P} 1)$ and wall, et'al(2010=P241) found that marketing mix take into account the following factors: promotion, products, price and place. These four elements are commonly known as the "4Ps" and are considered in more detail in the contest of international marketing strategies. However, the commonly "4Ps" can also serve as a player in the short-term action and reaction pattern of firms in context of marketing responses to product life cycle. These "4Ps" can be further analysing as follows.

Promotion strategy -This involve levels of emphasis put into advertising, sales promotion, technological change, personal selling, public relation etc.

The advertising- the coca cola popular saying "when you drink don't drive, drink coca cola" this remind us to do something. Therefore, advertising is act of keeping the consumers or user of a product inform about the existence and relevance of a product compare to others. The firm has to launch tactical and special method to bring consumers into notice about the existence of her product and why consumer must buy her products. Iganiga and Ikharehon( 2004$)$ in Effiong and Ekpenyong (2010=P27)state that "as advertising give reasons to buy the brand of the product or services, sales promotion offers incentives to buy the product". This further explains what advertising does in marketing of the product. According to Engel at'el (1991) in Effiong 
and Ekpenyong $(2010=$ =P27) state that advertising paid non personal communication through various media by business firms, non profit organisations, and individuals who are in some way identified in the advertising massage and who hope to inform and/or persuade members of a particular audience ; include communication of products, service, institution and ideas.

The sales promotion- For many business expert and academics, sales promotion is regarded as typical marketing techniques that add value to a product in order to achieve specific marketing goals Andromida (2011). However, the institute of sales promotion defines sales promotion as "a range of tactical marketing techniques, design within a strategic marketing framework, to add product or services, in order to achieve a specific sales and marketing objective, Chartered Institute of Marketing (2011). Just as admitted by Iganiga and Ikharehon (2004 ) in Effiong and Ekpenyong $(2010=\mathrm{P} 27)$ that "as advertising give reasons to buy the brand of the product or services, sales promotion offers incentives to buy the product".

Therefore, as a result of the above explanations, sales promotion is very important as it did not only help to boost sales but also help a firm to attract new customers and maintained older ones.

Technological change- technology has simplified almost all kinds of activities in the world. In marketing, it is a major driving force both in international marketing and in the move towards a more global market place. The impact of technological advancement can be seen in all aspect of the marketing process. The ability to gather data on market, management control capabilities and the practicalities of carrying out the business function internationally have been revolutionised in recent years with the advances in electronic communications. Satellite communications, the internet and the worldwide web, client server technologies, cable as well as email, faxes and advanced telephone network, have all led to dramatic shrinkages in worldwide communications. Access to information using all these gadgets is 24 hours a day service believed by Doole and Lowe $(2009=17)$

Products strategy-This involved the art of modifying the various stages, such as introduction, growth, maturity, decline etc, of the "product life cycle". Example, attempt may be made to extend the "maturity stage" by finding new markets for existing product, new uses for the product or modifying the product and after sales services and policy for customer care. All these activities help to facilitate the marketing of the firm's products.

Price strategy- this is use to predict the competitors responses. Price also helps to select particular pricing approaches for the firm product. Example "price skimming and price penetration" can be use. The former explain how price is allotted high in order to attract higher revenue and profit and the later explain how low price is set in, so as to reach a large market as possible in a short period of time. "Discriminating pricing" may also be allotted by the firm where lower prices can be charge for the same product in some market than the other.

Place strategy.-this involves selection of distribution channels, transport arrangement etc. For example pre eminence in distributional policy might be given to distributional channels such as selling from the producer to the consumer, producer to the retailer and producer to the wholesaler or franchising.

\section{The Evaluation Of Marketing Strategies Used By The Coca Cola Company In Nigeria}

The coca cola in Nigeria have used the strategy of marketing mix to market her products internationally. This strategy as earlier stated above takes into account different tactics which the coca cola company have survey and discovered it to be acceptable for the company to use in Nigeria. Under this marketing mix, the following tactics are used by the company to convince the consumers to patronise the coca cola product as the number one beverages drinks in Nigeria. This tactics employed by the coca cola company has four elements term "the 4Ps" which is express as, promotion, products, price and place. However, the basic task of marketing is combining these four elements into a marketing programme to facilitate the potentials for exchange with consumers in the market place.

Promotion tactics.- This explains the organisational total effort attempt to attained increase sales in the short run. The coca cola had spent a large sums of money on the given and provision of reasons and incentives to the middlemen and the consumers of the coca cola products to pull them to buy their products. As admit by Belch and Belch (2007 =P9) that "a firm can spend large sums of money on advertising or sales promotion but it stands little chance of success if the product is of poor quality, if priced improperly or does not have adequate distribution to consumers".

The coca cola company would continuous to grow in Nigeria because it spent much amount of money in sales promotion and advertising. For example the company organises different competitive shows in Nigeria tertiary institutions in the name of sales promotion and advertising, also towards the period of festivities such as Christmas and sallah, the company would always introduced one promotional activities or the other. In spites of all these activities, the coca cola company uninterruptedly grow. This is because the standardization of their product is appreciated and contributory to the fast growing of the company. This is what Michael porter term "jockeying for position" in his theory of five marketing strategies analysis, Wall, et'al(2010=P241). He further states that policies towards pricing, promotion, product innovation and services level must be analyse very well 
to successfully position the company for defence against competitive forces, influence the balance of forces through strategic move and anticipate changes in the factors underlying the forces and respond to them.

Product tactics.- this tends to explains the life cycle of a product. In Nigeria for example, the coca cola company since her establishment in Nigeria 1951, it is still growing and maturing, it's has not get to the declining stage Obi (2011). The international marketing managers have work well to know the basic needs of Nigerians on the aspects of beverages drinks. In fact most of the ethnic groups in Nigeria have included the coca cola drinks as one of the items listed on the bride price of their marriage rites particularly the EGGON EXTRATE in Nasarawa state. The coca cola in Nigeria over five years ago have introduced plastic bottles of the coca cola drinks alongside with the already existing bottles in which the consumer can buy anywhere in the country and disposed after used. This reduces the stress of buying and consumed at a spot and given back bottle. The coca cola dealers in Nigeria have a unique common characteristic of delivery the products in bits from kiosk to kiosk to their retailers at a uniform price. This activity is termed after sale services. It is believe that the coca cola company is discipline and acts accordance to the legal and political guide lines of the overseas societies. As found by Cateora and Graham $(2007=\mathrm{P} 13)$ that "the Indian Government, for example, gave the coca cola company the choice of either revealing its secret formula or leaving the country. The coca cola chose to leave. When it was welcomed back several years later, it faces harassment and constant interference with its operations from political activities, inspired by competing soft drink companies". All this effort put forward by coca cola Company in international marketing of their products has helped them to grow very well in Nigeria.

Kenneth Andrew SWOT and PESTLE theory is highly practice in their process of marketing. For example, new plastic coca cola bottles, after sales services obedience to the law etc are classified under external situation that the firm must cope with at the cause of international marketing of his product Wall, e'tal(2010 $=\mathrm{P} 240$ )

Price tactics.- price is the determinant of the forces of demand and supply by allocating resources among the consumers and the producers in the market. Here it is use to predict the competitors responses, it is also help to select particular pricing approaches for the firms' product. In Nigeria for example, the coca cola used what we called "price penetration". That is price set in, so as to cover a large market as possible in a short period of time. This is what the company use to capture the beverages market in Nigeria. If you go to any part of the country (Nigeria) today you would discovered that the price of the coca cola is uniform. However, it is also pertinent to know that the coca cola company in Nigeria neither practice price skimming, that is charging of high price in order to attract high revenue and profits nor discriminatory pricing where lower prices are charge for the same product in same market than in other.

The porters' analyses of treating customer as rivals are shown here. This is because no customer can attest to the formula use by the coca cola company to produce their product but the company have a friendly relationship with the customer in terms of performance and integrity.

Place tactics -this involve selection of distribution channels, transport arrangement etc. The Coca cola Company in areas of distributive channels has tried so much by reaching almost every part of Nigeria. The company is said to have twelve factory plants, sixty depots and over four hundred thousand dealers nationwide Obi (2011). The above expression shows that the coca cola company have a strong base in Nigeria in the areas of distribution channels. This also contributed to her fastest growing among the multinational enterprises in Nigeria.

\section{Conclusion}

In conclusion, the coca cola company in Nigeria has grown fast and well because it has used human oriented strategies which contributed to her ever growing in the country. Among the strategies make use of by the coca cola company that won the attention of the consumers to her products include; consistent advertising of the products, constant organisation of sales promotion activities, the production of standard products, provision of after sale services, obeying law and political structure of the country, introduction of disposable bottles of coca cola, charging of affordable prices for their products and finally the company has twelve strong factory plants, sixty depots and over four hundred thousand dealers of the coca cola products.

\section{Recommendation}

The coca cola company have tried much in international marketing of her products in Nigeria. However, the same factors that had pushed her up would as well pull her down if good sustainable measure is not taken. Therefore, the researchers recommend that firstly, the area of corporate social responsibility should be highly considered and should gear toward rural areas where highest population of developing economy like Nigeria are found. In the same vein the people oriented project should be executed. This would sustain and will also increase the level of demand for the coca cola products;

Secondly, in a country of over one hundred and sixty million people, the number of factory plants is just twelve which is very small, because most of the people need the coca cola products. Therefore factory 
plants should be increased to not less than twenty and the number of depots and dealers/retailers should be increased to have a wider coverage of the rural areas.

\section{References}

[1] Adromida (2011) sales promotion/marketing mix strategy and ideas and method (online): available at:http://andromida.hubpages.com/hub/co.

[2] Belch G.E. and Belch, M. A (2007) Advertising and Promotion. An integrated marketing communications perspective. Seventh edition.

[3] Bennett, R (1998 =1). International Marketing Strategy, Planning, Market entry and Implementation. Second edition.

[4] Cateora, P. R and Graham, J. L (2007) International Marketing. Thirteenth edition

[5] Chartered Institute of Marketing (2011) Marketing Planning Tools. (Online): available at: http://www.cim.co.uk/marketing planning tool.

[6] Doole, I. And Lowe, R. (2008=17) international marketing strategy analysis, development and implementation. Fifth edition

[7] Effiong, C. And Ekpenyon, O E(2010). The Strategic Management of the Advertising Massages in Nigeria. $2^{\text {nd }}$ annual international conference on economic, business and entrepreneurship in Africa. March $9^{\text {th }}-11^{\text {th }} 2010$. (Online): available at: http://www.intledgroup.com/uyouni 2010 proceeding.pdf

[8] Idio, U S(2010) marketing strategies for micro-finance bank: reflexions from failed community banks. $2^{\text {nd }}$ annual international conference on economic, business and entrepreneurship in Africa. March $9^{\text {th }}-11^{\text {th }}$ 2010. (Online): available at: http://www.intledgroup.com/uyouni 2010 proceeding.pdf

[9] Johnson G, Scholes K and Whittington, R.(2009) Exploring Corporate Strategy with my strategy lab. Eighth edition

[10] Obi, D.(2011). Branding -NBC unfolds plans for coca cola 60 years in Nigeria. (Online): business day. News you can trust. Available at: http://www.businessdayonline.com/NG/index.php

[11] Retroplanet(2008). a brief history of the coca cola company (online): available at: http://zimbio.com/coca-cola/article

[12] Wall S. Minocha S. And Rees B.(2010). international business. Third edition 